\section{The Effect of Daily Light Integral on Bedding Plant Growth and Flowering}

\author{
James E. Faust, Veronda Holcombe, Nihal C. Rajapakse, and \\ Desmond R. Layne \\ Department of Horticulture, D-136 P\&A Building, Clemson University, \\ Clemson, SC 29634
}

Additional index words. ageratum, begonia, impatiens, marigold, petunia, salvia, vinca, zinnia

\begin{abstract}
Daily light integral (DLI) describes the rate at which photosynthetically active radiation is delivered over a 24 -hour period and is a useful measurement for describing the greenhouse light environment. A study was conducted to quantify the growth and flowering responses of bedding plants to DLI. Eight bedding plant species [ageratum (Ageratum houstonianum L.), begonia (Begonia $\times$ semperflorens-cultorum L.), impatiens (Impatiens wallerana L.), marigold (Tagetes erecta L.), petunia (Petunia $\times$ hybrida Juss.), salvia (Salvia coccinea L.), vinca (Catharanthus roseus L.), and zinnia (Zinnia elegans L.)] were grown outdoors in direct solar radiation or under one of three shade cloths (50, 70 or $90 \%$ photosynthetic photon flux (PPF) reduction) that provided DLI treatments ranging from 5 to $43 \mathrm{~mol} \cdot \mathrm{m}^{-2} \cdot \mathrm{d}^{-1}$. The total plant dry mass increased for all species, except begonia and impatiens, as DLI increased from 5 to $43 \mathrm{~mol} \cdot \mathrm{m}^{-2} \cdot \mathrm{d}^{-1}$. Total plant dry mass of begonia and impatiens increased as DLI increased from 5 to $19 \mathrm{~mol} \cdot \mathrm{m}^{-2} \cdot \mathrm{d}^{-1}$. Impatiens, begonia, salvia, ageratum, petunia, vinca, zinnia, and marigold achieved $50 \%$ of their maximum flower dry mass at $7,8,12,14,19,20,22$, and $23 \mathrm{~mol} \cdot \mathrm{m}^{-2} \cdot \mathrm{d}^{-1}$, respectively. The highest flower number for petunia, salvia, vinca, and zinnia occurred at $43 \mathrm{~mol} \cdot \mathrm{m}^{-2} \cdot \mathrm{d}^{-1}$. Time to flower decreased for all species, except begonia and impatiens, as DLI increased to 19 or $43 \mathrm{~mol} \cdot \mathrm{m}^{-2} \cdot \mathrm{d}^{-1}$. There was no consistent plant height response to DLI across species, although the shoot and flower dry mass per unit height increased for all species as DLI increased from 5 to $43 \mathrm{~mol} \cdot \mathrm{m}^{-2} \cdot \mathrm{d}^{-1}$. Guidelines for managing DLI for bedding plant production in greenhouses are discussed.
\end{abstract}

Daily light integral (DLI) describes the rate at which photosynthetically active radiation is delivered over a $24-\mathrm{h}$ period. Weekly or monthly integrated totals are useful for determining plant growth responses or phenology (Pearcy, 1991). Korczynski et al. (2002) mapped the average monthly DLI for the contiguous United States, observing that the outdoor DLI ranged from a monthly average of 5 to $10 \mathrm{~mol} \cdot \mathrm{m}^{-2} \cdot \mathrm{d}^{-1}$ in December across the northern U.S. to 55 to $60 \mathrm{~mol} \cdot \mathrm{m}^{-2} \cdot \mathrm{d}^{-1}$ during June in the southwest U.S. While many commercial growers traditionally relied on light intensity measurements, e.g., footcandles, to quantify the solar radiation delivered to a crop, the increasing use of weather stations connected to greenhouse climate-control computers allows growers to access daily integrated solar radiation measurements.

The DLI delivered to greenhouse bench crops can vary tremendously based on the time of year, the greenhouse structure and cultural practices. DLI measured inside greenhouses typically ranges from 1 to $25 \mathrm{~mol} \cdot \mathrm{m}^{-2} \cdot \mathrm{d}^{-1}$, while $>25 \mathrm{~mol} \cdot \mathrm{m}^{-2} \cdot \mathrm{d}^{-1}$ is possible in greenhouses

Received for publication 18 May 2004. Accepted for publication 3 Sept. 2004. Technical contribution 5020 of the Clemson University Experiment Station. This material is based upon work supported by CSREES-USDA, under project number SC-1700135. Additional support for this research was provided by FIRST. Any opinions, findings, conclusions or recommendations expressed in this publication are those of the authors and do not necessarily reflect the view of the USDA. equipped with retractable shade curtains or in retractable roof greenhouses. DLI measured inside the greenhouse is lower than outside levels due to reflection and absorption of photons by the greenhouse infrastructure and glazing material. The greenhouse infrastructure may reduce DLI by as much as 40\% (Hanan, 1998). Shade curtains, which are used to help manage greenhouse temperatures during periods of high solar radiation, typically reduce the DLI by $40 \%$ to $80 \%$. Supplemental lighting can increase the DLI delivered to the greenhouse crop; however, commercial lighting levels typically provide $<4 \mathrm{~mol} \cdot \mathrm{m}^{-2} \cdot \mathrm{d}^{-1}$ (Spaargaren, I.J. 2000). The DLI reaching the crop on the bench may be reduced by overhead hanging basket production by as much as $45 \%$ depending on hanging basket color, density, and plant size (Korczynski, 2000).

Several studies have described the effect of DLI on the growth and development of bedding plants. Plant growth measured in terms of dry mass accumulation, leaf area, and plant height are affected by DLI. For example, White and Warrington (1984) observed an increase in geranium plant dry mass from 2.9 to $3.4 \mathrm{~g}$ as the DLI increased from 6.5 to $19.4 \mathrm{~mol} \cdot \mathrm{m}^{-2} \cdot \mathrm{d}^{-1}$, while the leaf area per plant decreased from 1047 to $820 \mathrm{~cm}^{2}$ as DLI increased from 8.7 to $20.5 \mathrm{~mol} \cdot \mathrm{m}^{-2} \cdot \mathrm{d}^{-1}$. Niu et al. (2000) reported that the dry mass of pansy 'Delta Yellow Blotch' increased by $40 \%$ as the DLI increased from 4.1 to $10.6 \mathrm{~mol} \cdot \mathrm{m}^{-2} \cdot \mathrm{d}^{-1}$. Kaczperski et al. (1991) reported that petunias grown at $6.5 \mathrm{~mol} \cdot \mathrm{m}^{-2} \cdot \mathrm{d}^{-1}$ were up to $6 \mathrm{~cm}$ taller than plants grownunder
$13.0 \mathrm{~mol} \cdot \mathrm{m}^{-2} \cdot \mathrm{d}^{-1}$. DLI also affects flowering in terms of the rate of flower development and flower size. For example, increasing the DLI delivered to geraniums from 3.2 to 24.3 $\mathrm{mol} \cdot \mathrm{m}^{-2} \cdot \mathrm{d}^{-1}$ resulted in a $29-\mathrm{d}$ decrease in time to visible bud; however, DLI did not affect the time from visible bud to flower (Armitage et al., 1981). Time to flower for petunia decreased by 3 weeks as DLI increased from 6.5 to 13.0 $\mathrm{mol} \cdot \mathrm{m}^{-2} \cdot \mathrm{d}^{-1}$ (Kaczperski et al., 1991). Pansy flower size increased by $25 \%$ and time to flower decreased by 4 to $12 \mathrm{~d}$, depending on cultivar, when DLI increased from 4.1 to 10.6 $\mathrm{mol} \cdot \mathrm{m}^{-2} \cdot \mathrm{d}^{-1}$ (Niu et al. 2000).

Managing the irradiance delivered to the greenhouse crop is critical for successful bedding plant production and greenhouse business profitability. Irradiance can be manipulated with supplemental lighting, shade curtains, retractable roofs and hanging basket production. A greater understanding of bedding plant responses to DLI will improve growers' ability to more effectively utilize greenhouse space and manipulate the irradiance delivered to bedding plant crops. Therefore, the objective of this study was to quantify the effect of DLI on the growth and flowering of eight bedding plant species.

\section{Materials and Methods}

Ageratum (Ageratum houstonianum L. 'Hawaii White') and begonia (Begonia $\times$ semperflorens-cultorum L. 'Vodka Cocktail') plugs $\left(13.6-\mathrm{cm}^{3}\right.$ cells) were received on 10 May from a commercial plug supplier (Wagner's Greenhouses, Minneapolis, Minn.). Impatiens (Impatiens wallerana L. 'Cajun Red'), petunia (Petunia $\times$ hybrida Juss. 'Apple Blossom'), salvia (Salvia coccinea L. 'Lady in Red'), and vinca (Catharanthus roseus L. 'Pacific Lilac') plugs (3.1- $\mathrm{cm}^{3}$ cells) and marigold (Tagetes erecta L. 'American Antigua Orange') and zinnia (Zinnia elegans L. 'Dreamland Rose') plugs (3.9- $\mathrm{cm}^{3}$ cells) were received on 11 May from a commercial plug supplier (Raker's Acres, Litchfield, Mich.). Plants of all eight species were transplanted into 10 -cm-diameter $\left(454-\mathrm{cm}^{3}\right)$ containers on 11 May and placed in the experimental treatments three days later.

Sixteen shade structures $(2.1 \times 2.1 \times 1.0$ $\mathrm{m}$, length $\times$ width $\times$ height) were located outdoors on a gravel bed ( $34^{\circ} \mathrm{N}$ Lat., Clemson, S. Carol.). Four shade levels $(0 \%, 50 \%, 70 \%$, and $90 \%$ PPF reduction) were provided by covering the structures with neutral density shade fabric (Green Tec; Mississauga, Ontario, Canada). Thirty plants each of ageratum, begonia, geranium, and impatiens were placed under eight of the shade structures with each shade treatment being replicated twice. Thirty plants each of marigold, petunia, salvia, vinca and zinnia were placed under the other eight shade structures with each shade treatment replicated twice. For all species, plants were placed at $10 \times 10 \mathrm{~cm}$ spacing until the leaves began to touch and were then placed at $20 \times 20$ $\mathrm{cm}$ spacing. Within each shade structure, data were collected on the twelve interior plants of each species, and no data were collected on the surrounding eighteen guard row plants. 
PPF was continuously measured at $60-\mathrm{s}$ intervals under one shade structure of each shade treatment using quantum line sensors (Apogee Instruments, Logan, Utah), and hourly average PPF was recorded with a quantum integrator (Apogee Instruments, Logan, Utah). Air temperatures in each shade structure were monitored with a Microprocessor Thermometer(Omega, Stamford, CT). The average daily temperature was $23.8,22.8,22.5$, and $22.3{ }^{\circ} \mathrm{C}$ in the $0 \%, 50 \%, 70 \%$, and $90 \%$ PPF reduction treatments, respectively.

A peat-based growing medium (Fafard 2B Mix, Fafard, Anderson, S.C.) was used. Plants were fertilized at a rate of $300 \mathrm{mg} \cdot \mathrm{L}^{-1}$ $\mathrm{N}$ with Peat-Lite Special (20N-8.6P-16.6K) (O.M. Scott, Marysville, Ohio) as necessary to maintain a media electrical conductivity in the range of 1.5 to $2.0 \mu \mathrm{S} \cdot \mathrm{cm}^{-1}$. The growing medium electrical conductivity was monitored weekly with an Agri-Meter (Myron L Company, Carlsbad, Calif.). Plants were irrigated with impact sprinklers that operated for twenty minutes, three times daily. The shade structures caused some water to be deflected away from the underlying plants, so individual plants were also watered daily with a hose as needed to maintain uniformity within and between treatments.

Data collection and analysis. The day that the first flower opened was recorded on individual plants during the experiment. Final harvest data were collected at day $32,38,37$, $48,37,39,53$, and 45 for ageratum, begonia, impatiens, marigold, petunia, salvia, vinca, and zinnia, respectively. The following data
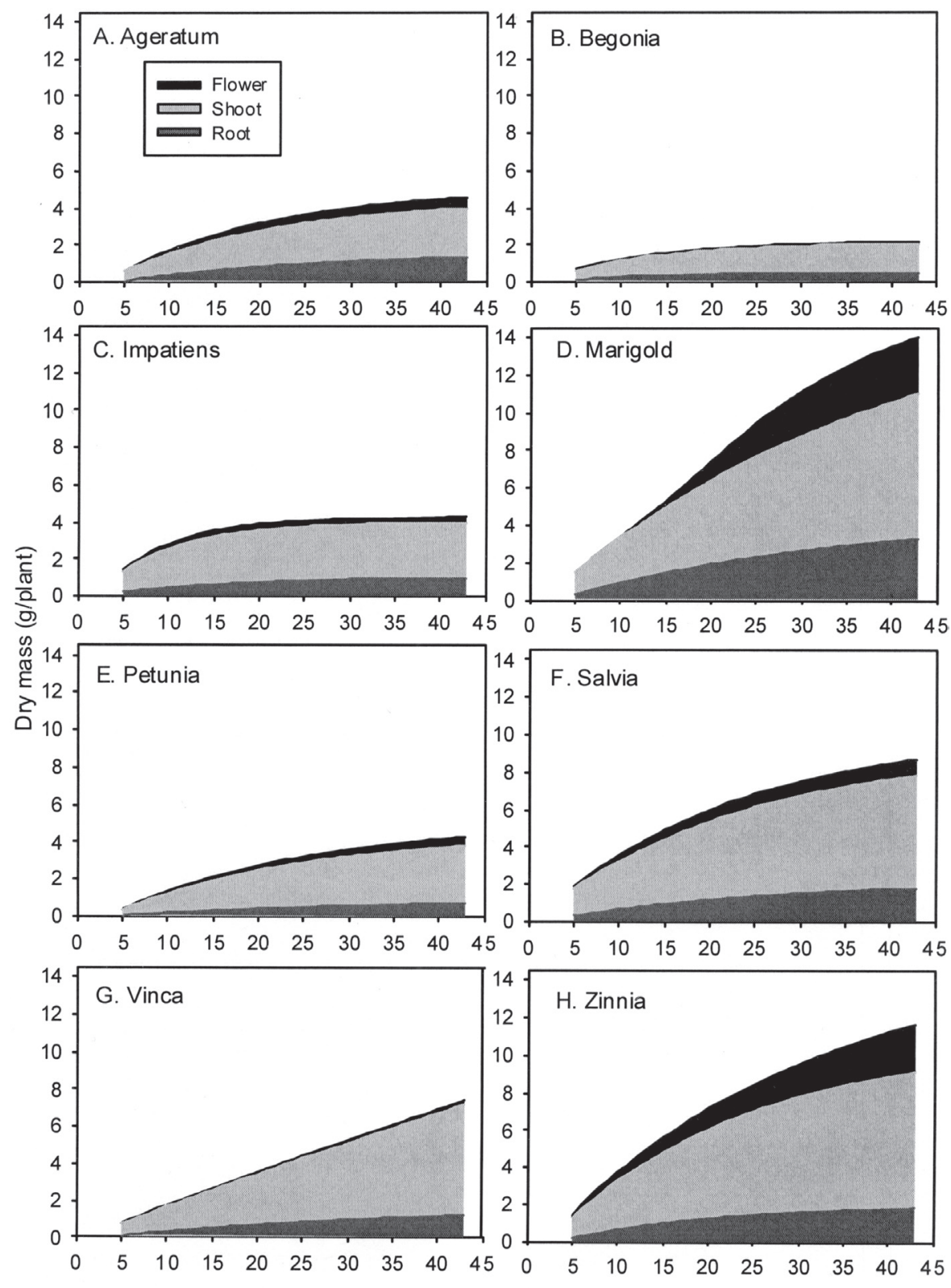

Average daily light integral $\left(\mathrm{mol} \cdot \mathrm{m}^{-2} \cdot \mathrm{d}^{-1}\right)$

Fig. 1. Stacked area graphs displaying the effect of average daily light integral (DLI) on the dry mass accumulation of eight bedding plant species. Linear and non-linear functions were used to individually describe the root, shoot, and flower and bud dry mass responses to DLI (Table 1) while the sum of the individual dry mass components represents the total plant dry mass. were collected: shoot, root and flower fresh and dry mass, plant height, leaf area, flower or inflorescence number, and flower diameter. The number of lateral shoots was recorded for ageratum and petunia. Flower fresh and dry mass included the open flowers and unopened buds. Dry mass was measured after placing the tissue in a $70{ }^{\circ} \mathrm{C}$ oven for $3 \mathrm{~d}$. Plant height was measured from the top of the pot to the uppermost shoot or flower.

The average DLI measured and the standard errors were $42.9 \pm 1.8,19.4 \pm 0.8,11.6 \pm 0.5$, and $4.8 \pm 0.2 \mathrm{~mol} \cdot \mathrm{m}^{-2} \cdot \mathrm{d}^{-1}$ for the $0 \%, 50 \%, 70 \%$, and $90 \%$ shade treatments, respectively, over $53 \mathrm{~d}$. Since data were collected on different dates for each species, each species received a slightly different mean DLI. The maximum differences between species for a particular shade treatment were $<6 \%$ of the mean DLI. Therefore, the DLI for the $0 \%, 50 \%, 70 \%$, and $90 \%$ shade treatments will be referred to as 43 , 19,12 , and $5 \mathrm{~mol} \cdot \mathrm{m}^{-2} \cdot \mathrm{d}^{-1}$, respectively.

The experiment was a completely randomized design with two replications and 12 samples per replication. ANOVA was performed with PROC GLM (SAS Institute, Inc. Cary, N.C.). Significant growth responses were described with regression lines fitted with Sigma Plot 2002 for Windows Version 8.02 (SPSS Inc., Chicago). Tukey's studentized range test $(5 \%$ level) was used to determine treatment differences on the flowering data.

\section{Results}

Total plant dry mass increased at a decreasing rate as DLI increased from 5 to 43 $\mathrm{mol} \cdot \mathrm{m}^{-2} \cdot \mathrm{d}^{-1}$ for all species (Fig. 1). Linear and nonlinear regression equations were used to describe the root, shoot and flower dry mass responses to DLI (Table 1). Root dry mass of all species was accurately described with an exponential equation. The same equation also described shoot dry mass for all species except vinca which displayed a linear response to DLI. Flower dry mass response to DLI varied among species. Flower dry mass of four species (ageratum, begonia, petunia and salvia) exhibited an exponential rise to a maximum response to DLI. Vinca and zinnia flower dry mass increased linearly as DLI increased. Marigold required a sigmoidal curve since flower dry mass displayed a relatively large increase as DLI increased from 12 to $19 \mathrm{~mol} \cdot \mathrm{m}^{-2} \cdot \mathrm{d}^{-1}$. A log normal equation was used to describe impatiens flower dry mass which exhibited a peak at $19 \mathrm{~mol} \cdot \mathrm{m}^{-2} \cdot \mathrm{d}^{-1}$.

Plant growth analysis displayed consistent trends amongst all eight species (Fig. 2). Leaf area per gram of plant dry mass displayed an exponential decay response $[\mathrm{y}=\mathrm{a}+\mathrm{b}$ $\operatorname{EXP}(-c x)]$ to increasing DLI. Thus, the leaf area required to support an equal amount of plant tissue decreased as DLI increased (Fig. $2 \mathrm{~A}$ and $\mathrm{B}$ ). The above ground dry mass, i.e., shoot and flower, per unit height increased at a decreasing rate $[y=a+b(1-\operatorname{EXP}(-c X))]$ as DLI increased (Fig. 2C and D). This measurement, in part, reflects the effect of DLI on lateral shoot development. Lateral shoot data were collected on ageratum and petunia. 
Table 1. Regression equations and $R^{2}$ values for the root, shoot and flower dry mass for eight bedding plant species, where $\mathrm{X}$ is the daily light integral (DLI). Plots of each equation are shown in Fig. 1.

\begin{tabular}{lclc}
\hline Species & Dry mass & Regression equation & $R^{2}$ \\
\hline Ageratum & Root & $-0.304+1.89(1-\exp (-0.0489 \mathrm{X}))$ & 0.980 \\
& Shoot & $-0.190+3.09(1-\exp (-0.0592 \mathrm{X}))$ & 0.991 \\
& Flower & $-0.150+0.816(1-\exp (-0.0589 \mathrm{X}))$ & 0.958 \\
Begonia & Root & $-0.260+0.742(1-\exp (-0.160 \mathrm{X}))$ & 0.926 \\
& Shoot & $0.158+1.58(1-\exp (-0.0633 \mathrm{X}))$ & 0.883 \\
& Flower & $-0.027+0.114(1-\exp (-0.122 \mathrm{X}))$ & 0.710 \\
Impatiens & Root & $-0.0167+1.15(1-\exp (-0.0592 \mathrm{X}))$ & 0.757 \\
& Shoot & $-0.919+3.90(1-\exp (-0.157 \mathrm{X}))$ & 0.963 \\
& Flower & $0.343 \exp \left(-0.5(\ln (\mathrm{X} / 20.3) / 0.929)^{2}\right.$ & 0.896 \\
Marigold & Root & $-0.347+4.97(1-\exp (-0.0311 \mathrm{X}))$ & 0.990 \\
& Shoot & $-0.0705+11.8(1-\exp (-0.0251 \mathrm{X}))$ & 0.939 \\
& Flower & $3.25 /\left(1+(\mathrm{X} / 23.6)^{-4.47}\right)$ & 0.923 \\
Petunia & Root & $-0.925+1.08(1-\exp (-0.0332 \mathrm{X}))$ & 0.985 \\
& Shoot & $-0.552+4.05(1-\exp (-0.0519 \mathrm{X}))$ & 0.953 \\
& Flower & $-0.0574+0.907(1-\exp (-0.0223 \mathrm{X}))$ & 0.969 \\
Salvia & Root & $-0.0898+2.33(1-\exp (-0.0404 \mathrm{X}))$ & 0.957 \\
& Shoot & $-0.229+6.81(1-\exp (-0.0449 \mathrm{X}))$ & 0.992 \\
& Flower & $-0.248+1.16(1-\exp (-0.0727 \mathrm{X}))$ & 0.968 \\
Vinca & Root & $-0.145+1.96(1-\exp (-0.0288 \mathrm{X}))$ & 0.991 \\
& Shoot & $0.0187+0.140 \mathrm{X}$ & 0.962 \\
& Flower & $0.0143+0.00480 \mathrm{X}$ & 0.988 \\
Zinnia & Root & $-0.390+2.40(1-\exp (-0.0590 \mathrm{X}))$ & 0.980 \\
& Shoot & $-0.609+9.26(1-\exp (-0.0451 \mathrm{X}))$ & 0.981 \\
& Flower & $-0.0978+0.0626 \mathrm{X}$ & 0.989 \\
\hline
\end{tabular}

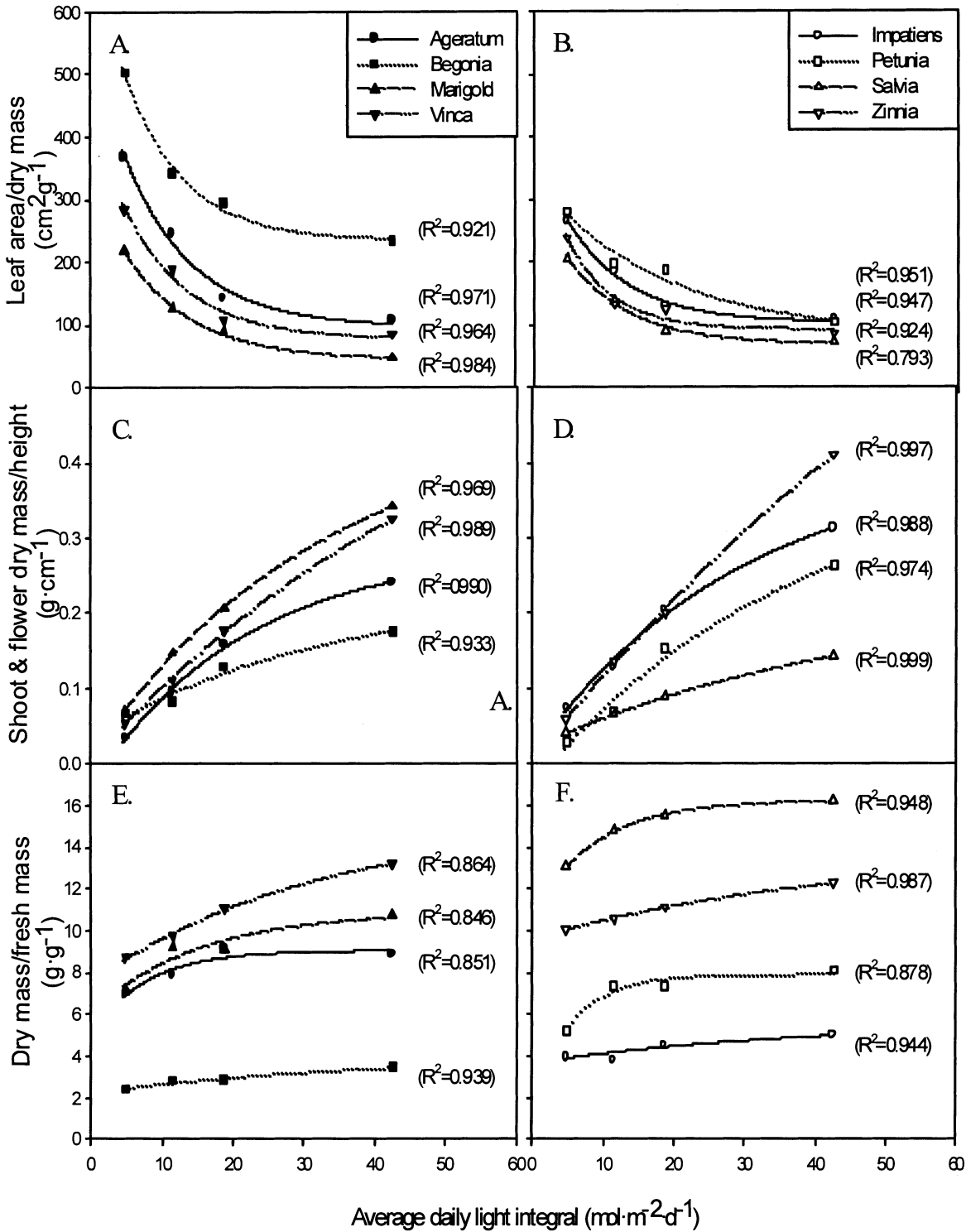

For petunia, the number of lateral shoots per plant was $1.7,4.2,8.3$, and 8.8 for the 5,12 , 19 , and $43 \mathrm{~mol} \cdot \mathrm{m}^{-2} \cdot \mathrm{d}^{-1}$ treatments, respectively. For ageratum, the number of lateral shoots was $2.9,5.5,8.3$, and 9.9 for the $5,12,19$, and $43 \mathrm{~mol} \mathrm{~m}^{-2} \cdot \mathrm{d}^{-1}$ treatments, respectively. The ratio of plant dry mass per gram of fresh mass increased as DLI increased (Fig. 2E and F). Begonia, impatiens and zinnia displayed a nearly linear response as DLI increased, while the other five species increased at a decreasing rate $[\mathrm{y}=\mathrm{a}+\mathrm{b}(1-\operatorname{EXP}(-\mathrm{cx}))]$.

Plant height response to DLI varied with species (Fig. 3). Marigold was the only species to increase height as DLI increased from 5 to $43 \mathrm{~mol} \cdot \mathrm{m}^{-2} \cdot \mathrm{d}^{-1}$. In contrast, ageratum and petunia height decreased as DLI increased from 5 to $43 \mathrm{~mol} \cdot \mathrm{m}^{-2} \cdot \mathrm{d}^{-1}$. Begonia and impatiens height increased as DLI increased from 5 to $12 \mathrm{~mol} \cdot \mathrm{m}^{-2} \cdot \mathrm{d}^{-1}$, then decreased at higher DLI. Salvia and zinnia height increased as DLI increased from 5 to $19 \mathrm{~mol} \cdot \mathrm{m}^{-2} \cdot \mathrm{d}^{-1}$, then decreased as DLI increased to $43 \mathrm{~mol} \cdot \mathrm{m}^{-2} \cdot \mathrm{d}^{-1}$. Vinca height did not change from 5 to 19 $\mathrm{mol} \cdot \mathrm{m}^{-2} \cdot \mathrm{d}^{-1}$, then increased as DLI further increased to $43 \mathrm{~mol} \cdot \mathrm{m}^{-2} \cdot \mathrm{d}^{-1}$.

Time to flower decreased as DLI increased for ageratum, petunia, salvia, and zinnia (Table 2 ). Time to flower for impatiens was not affected by DLI, while begonia time to flower increased as DLI increased. Marigold did not flower at 5 and $12 \mathrm{~mol} \cdot \mathrm{m}^{-2} \cdot \mathrm{d}^{-1}$ during the experiment, although flower buds were present in the $12 \mathrm{~mol} \cdot \mathrm{m}^{-2} \cdot \mathrm{d}^{-1}$ treatment when data were collected. Flower number of marigold, petunia, vinca, and zinnia was highest at 43 $\mathrm{mol} \cdot \mathrm{m}^{-2} \cdot \mathrm{d}^{-1}$. Flower number of begonia and impatiens nearly doubled as DLI increased from 5 to $19 \mathrm{~mol} \cdot \mathrm{m}^{-2} \cdot \mathrm{d}^{-1}$. Zinnia was the only species for which the flower diameter had a horticulturally significant response to DLI.

\section{Discussion}

The DLI delivered to crops inside greenhouses in the U.S. typically ranges from 1 to $25 \mathrm{~mol} \cdot \mathrm{m}^{-2} \cdot \mathrm{d}^{-1}$, while outdoor DLI levels can exceed $50 \mathrm{~mol} \cdot \mathrm{m}^{-2} \cdot \mathrm{d}^{-1}$. The DLI inside greenhouses rarely exceeds $25 \mathrm{~mol} \cdot \mathrm{m}^{-2} \cdot \mathrm{d}^{-1}$ due to the use of shade curtains when the outdoor irradiance is high $\left(>35 \mathrm{~mol} \cdot \mathrm{m}^{-2} \cdot \mathrm{d}^{-1}\right)$. The increased growth observed on several species in this study above $19 \mathrm{~mol} \cdot \mathrm{m}^{-2} \cdot \mathrm{d}^{-1}$ underscores the potential value of greenhouses equipped with retractable shade curtains and retractable roofs for bedding plant production, since higher DLI can be provided compared to traditional, fixed-shade greenhouses.

Fig. 2. Effect of average daily light integral (DLI) on the growth analysis of eight bedding plant species. The growth analyses include (A and $\mathbf{B})$ the leaf area per unit plant dry mass $\left(\mathrm{cm}^{2} \cdot \mathrm{g}^{-1}\right),(\mathbf{C}$ and $\mathbf{D})$ the shoot and flower dry mass per unit height $\left(\mathrm{g} \cdot \mathrm{cm}^{-1}\right)$ and $(\mathbf{E}$ and $\mathbf{F})$ dry mass per fresh mass $\left(g \cdot g^{-1}\right)$. The eight species were divided into two groups of four for the purposes of clarity within each figure. Datapoints represent the mean of 24 plants. 


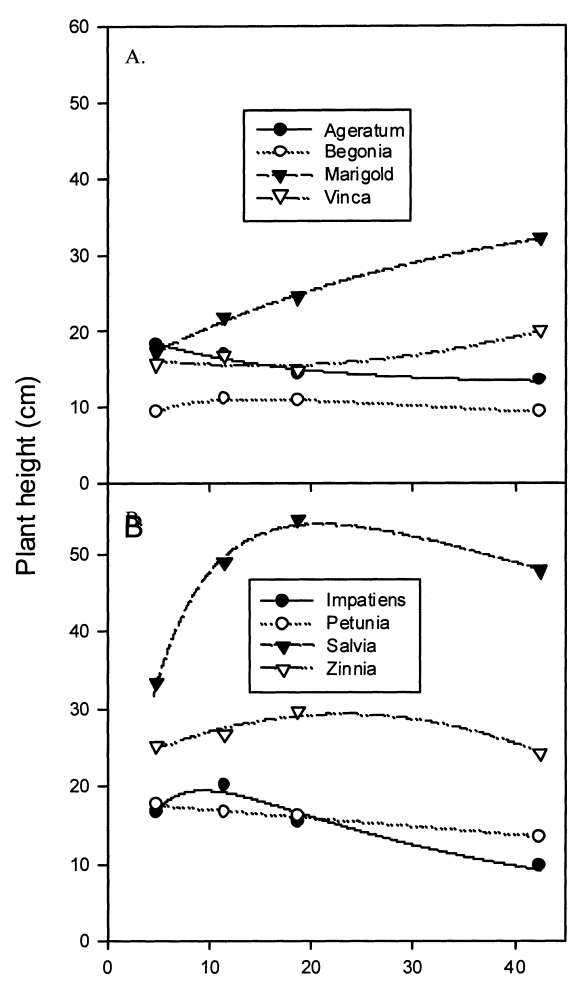

Average daily light integral $\left(\mathrm{mol} \cdot \mathrm{m}^{-2} \cdot \mathrm{d}^{-1}\right)$

Fig. 3. Plant height responses of eight bedding plant species to the average daily light integral (DLI). The eight species were divided into two groups of four for the purposes of clarity within each figure. Datapoints represent the mean of 24 plants.

The growth analyses presented in Fig. 2 provide an indication of plant quality. Shoot dry mass per unit height provides a measurement of canopy density, while the dry mass per unit fresh mass provides an indication of what commercial growers refer to as toning. As DLI increased, the dry mass per unit fresh mass increased which resulted in thicker tissues that are often considered a desirable commercial quality. These tissues have a higher proportion of structural materials and carbohydrates per unit fresh weight. In contrast, plants grown under low DLI were softer, i.e., they had a higher percentage of water in the above ground tissues. Although, the growth of all species increased as DLI increased, begonias and impatiens grown at $43 \mathrm{~mol} \cdot \mathrm{m}^{-2} \cdot \mathrm{d}^{-1}$ were commercially unsatisfactory. Begonia had thick, brittle leaves with a reddish color, while impatiens had cupped, chlorotic leaves.

Professional horticulturists often make the assumption that plant height increases under low irradiance conditions; however, our data suggest no consistent relationship between DLI and plant height across different species. In part, this is a reflection of the experimental protocol and the fact that when irradiance is altered, several other factors that impact plant height are also affected. Our experimental protocol aimed to minimize treatment differences in the nutrition available (media EC), media water content (drought stress) and the shading caused by neighboring plants. In commercial production environments, low DLI environments correspond to lower irrigation requirements which often result in higher humidity, higher media water content and lower media EC. Also, in this experiment, height data were collected at one point in time. If data were to be collected at a particular stage of development, e.g., first open flower, the treatments that were slower to develop flowers would have had more time to elongate than the treatments that flowered quickly.

It is apparent that one can not generalize the effect DLI has on plant height. We suspect that in commercial greenhouses, low DLI conditions coincide with reduced water stress, delayed flower initiation, larger leaves, and reduced lateral branching. This combination of factors may result in taller plants due to the lack of water stress, increased node number, and a reduced red to far-red light ratio. It is also possible that low DLI conditions produce plants that are perceived to be taller due to the poor plant quality, i.e., a lack of branching, delayed flowering, and low flower number. Our data show that plant growth and quality are diminished at low DLI; however, low DLI does not necessary cause plants to grow taller.
Flowering of marigold, petunia, and zinnia was greatly affected by DLI. While other species showed significantflowering responses to DLI, the differences were relatively small and might be a result of the temperature differences associated with the different DLI. Commercially-grown plugs were used for each experiment. Since flower initiation can occur very quickly after seed germination of many bedding plants, it is possible that flower initiation had occurred prior to the start of the experiment for some species (Cerny et al., 2003). In general, if the DLI is sufficient to support flowers, then time to flower is primarily a function of the average daily temperature and DLI modifies the temperature response slightly (Faust and Heins, 1994). As DLI approaches the lower limit required for flowering, the time to flower increases. Interestingly, marigold and zinnia are in the Asteraceae family in which the inflorescence is a composite composed of many small flowers. For these two species, the flower dry mass of plants grown in full sunlight comprised $22 \%$ of the total plant dry mass which was considerable higher than the other species.

Categorizing individual species responses to DLI is useful for commercial producers. Moe (1994) proposed the following five DLI categories: 5 to $10 \mathrm{~mol} \cdot \mathrm{m}^{-2} \cdot \mathrm{d}^{-1}$ for low light crops, 10 to $20 \mathrm{~mol} \cdot \mathrm{m}^{-2} \cdot \mathrm{d}^{-1}$ for medium light crops, 20 to $30 \mathrm{~mol} \cdot \mathrm{m}^{-2} \cdot \mathrm{d}^{-1}$ for high light crops, and $>30 \mathrm{~mol} \cdot \mathrm{m}^{-2} \cdot \mathrm{d}^{-1}$ for very high light crops. One method for quantifying the DLI requirements for different species in this study was to use the regression equations in Table 1 to calculate the DLI required for each species to achieve $50 \%$ of the maximum total plant dry mass and $50 \%$ of the maximum flower dry mass. Impatiens, begonia, salvia, ageratum, petunia, zinnia, marigold, and vinca achieved $50 \%$ of the maximum total plant dry mass at $7,8,12$, $13,15,15,19$, and $21 \mathrm{~mol} \cdot \mathrm{m}^{-2} \cdot \mathrm{d}^{-1}$, respectively, while $50 \%$ of the maximum flower dry mass was achieved at 7, 8, 12, 14, 19, 22, 23, and 20 $\mathrm{mol} \cdot \mathrm{m}^{-2} \cdot \mathrm{d}^{-1}$, respectively. Visual observations indicated that begonia and impatiens were the only species that produced commercially ac-

Table 2. The effect of average daily light integral on the flowering of eight bedding plant species. The treatments were provided with shade cloth $(0 \%, 50 \%, 70 \%$, $90 \%$ ) placed over the plants grown outdoors. Data represent the mean of 24 plants. Within a species, all data from the different treatments were collected on the same day.

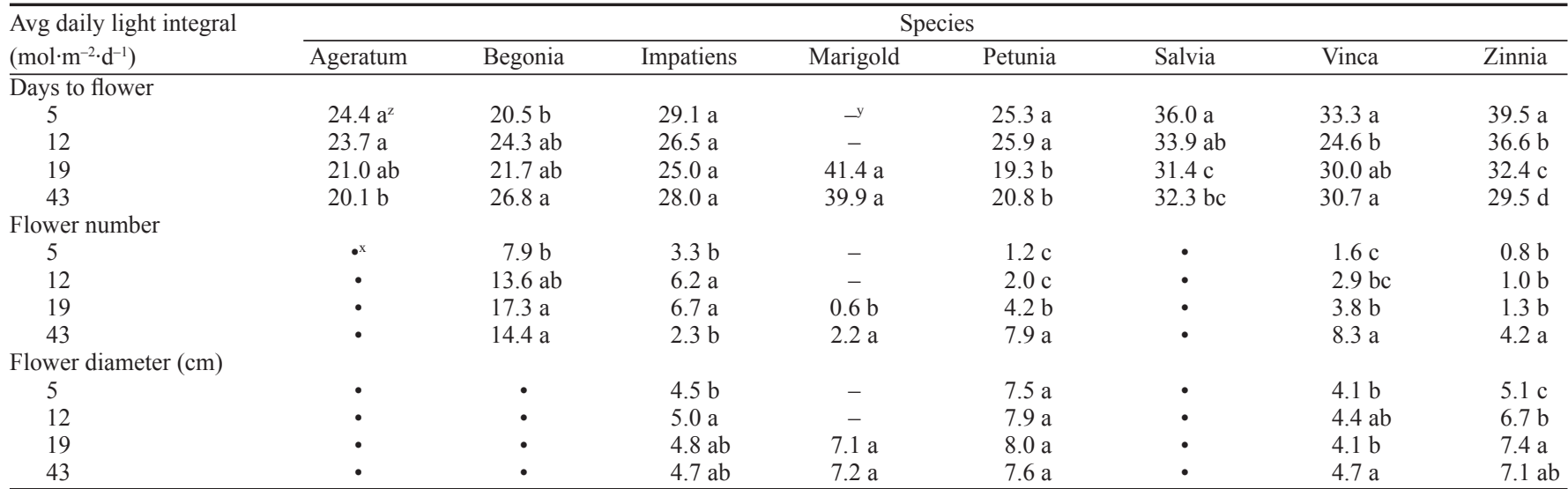

${ }^{2}$ Mean separation within species (columns) using Tukey's studentized range test (5\% level).

'Dash (-) indicates that the plants did not flower during the experiment.

${ }^{x} \operatorname{Dot}(\bullet)$ indicates that no data were collected. 
ceptable plants at $5 \mathrm{~mol} \cdot \mathrm{m}^{-2} \cdot \mathrm{d}^{-1}$, however the optimal growth and development occurred from 12 to $19 \mathrm{~mol} \cdot \mathrm{m}^{-2} \cdot \mathrm{d}^{-1}$. All species in our study, exceptmarigold, produced commercially acceptable plants at $12 \mathrm{~mol} \cdot \mathrm{m}^{-2} \cdot \mathrm{d}^{-1} ;$ however, 19 $\mathrm{mol} \cdot \mathrm{m}^{-2} \cdot \mathrm{d}^{-1}$ resulted in improved plant growth and quality for all species. Full sunlight (43 $\left.\mathrm{mol} \cdot \mathrm{m}^{-2} \cdot \mathrm{d}^{-1}\right)$ resulted in substantially improved growth and flowering for marigold, petunia, vinca, and zinnia. Therefore, impatiens and begonia could be categorized as low to medium DLI crops, i.e., low DLI is acceptable, but medium DLI is optimal. Similarly, salvia and ageratum could be categorized as medium to high DLI crops, and petunia, marigold, zinnia and vinca could be categorized as high to very high DLI crops.

\section{Literature Cited}

Armitage, A.M., W.H.Carlson, and J.A.Flore. 1981. The effect of temperature and quantum flux density on the morphology, physiology, and flowering of hybrid geraniums. J. Amer. Soc. Hort. Sci. 106:643-647.

Cerny, T.A., J.E. Faust, D.R. Layne, and N.C. Rajapakse. 2003. Influence of photoselective films and growing season on stem growth and flowering of six plant species. J.Amer. Soc. Hort. Sci. 128:486-491.

Faust, J.E. and R.D. Heins. 1994. Modeling inflorescence development of the african violet (Saintpaulia ionantha). J. Amer. Soc. Hort. Sci. 119:727-734

Hanan, J. 1998. Greenhouses: Advanced technology for protected horticulture, p. 15-165. CRC Press, Boca Raton, Fla.

Kaczpereski, M.P., W.H. Carlson, and M.G. Karlsson. 1991. Growth and development of Petunia $\times$ hybrida as a function of temperature and irradiance. J. Amer. Soc. Hort. Sci. 116:232-237.

Korczynski, P.C. 2000. Light and the greenhouse environment. MS thesis. Univ. Tenn.

Korczynski, P.C., J. Logan, and J.E. Faust. 2002. Mapping monthly distribution of daily light integrals across the contigous United States. HortTechnology 12:12-16.

Moe, R. 1994. Vekstfysiologiske aspekter med høege belysningsstyrker. Gartneryrket 84:8-13.

Niu, G., R. Heins, A. Cameron, and W. Carlson. 2000. Day and night temperature, daily light integral, and $\mathrm{CO}_{2}$ enrichment affect growth and flower development of pansy (Viola $\times$ wittrockiana). J. Amer. Soc. Hort. Sci. 125:436-441.

Pearcy, R.W. 1991. Radiation and light measurements, p. 97-116. In: R.W. Pearcy, J. Ehleringer, H.A.Mooney, and P.W. Rundel. (eds.). Plant physiological ecology: Field methods and instrumentation. Chapman and Hall, New York.

Spaargaren, I.J. 2000. Supplemental lighting for greenhouse crops. Hortilux Schreder, Amersterdam, Netherlands.

White, J. and I. Warrington. 1984. Effects of splitnight temperatures, light, and chlormequat on growth and carbohydrate status of Pelargonium $\times$ hortorum. J. Amer. Soc. Hort. Sci. 109:458-463. 